\title{
PHILOSOPHICAL THOUGHT OF AL-KINDI AND AL-FARABI
}

\author{
Ida IImiah Mursidin \\ Alauddin State Islamic University of Makassar \\ Email : mursidinidailmiah@gmail.com
}

\begin{abstract}
This study has two purposes, both are: 1) To describe Al-Kindi's thoughts about the harmony between philosophy and religion, and the theory of divine philosophy. 2) To describe Al-Farabi's thoughts about the theory of emanation, and the theory of divinity. This research is using a qualitative method which its study focused on library research. Data sources used in this research are the works related to the two figures as well as other philosophical thought books. The results obtained from this study are; First, according to Al-Kindi, philosophy and religion make no difference because both are equally knowledgeable about truth. The function of philosophy is not to sue the truth of revelation, to demand superiority or to demand equality with revelation. Philosophy does not make a claim as the highest way to reach the truth and want to humble itself as a support for revelation. God theory according to him God is a form that actually does not come from nothing into existence, not preceded by other forms, could not be divided and there are no other substances that equal Him. Secondly, AlFarabi about the emanations theory explained that God exists for the sake of His self. Through this research, it is expected to provide an understanding of the community about Muslim philosophy and its thoughts.
\end{abstract}

\section{Keyword: Philosophical Thought, Al-Kindi, Al-Farabi}

\section{INTRODUCTION}

\section{INTRODUCTION}

Talk about Islamic philosophy can not be separated from philosophy in general. Philosophical thinking is the result of human effort that is mutually sustainable throughout the universe. However, philosophical thinking in the sense of radical free and deep thinking, which is not influenced by doctrine and tradition, is sponsored by Greek philosophers (philosophers). History has recorded that the person who first learned and taught philosophy from Sophia or sophists (500-400 BC) was Socrates (469-399 BC), then passed on by Plato (427-457 BC), then continued again by his student named Aristotle (384-322 BC). After the time of Aristotle, history did not record 
the next generation of philosophers until al-Kindi was born the figure of the first Muslim philosopher during the reign of the Daulah Abbasiyyah $(132-656 \mathrm{H}){ }^{1}$

An Italian scholar of the Renaissance era, Geralomo Cardano (1501-1575 AD) stated that Al-Kindi was one of the 12 greatest thinkers in the Middle Ages. In the eyes of the historian Ibn Al-Nadim, Al-Kindi was the best man of his age. He mastered various sciences.

Then Al-Farabi made his appearance. Al-Farabi was a commentator on Greek philosophy who was very accomplished in the Islamic world. Even though he most likely did not speak Greek, he knew Greek philosophers, especially Plato, Aristotle, and Plotinus well. His contribution lies in various fields such as mathematics, philosophy, medicine, and even music. Al-Farabi had written various books on sociology and an important book in the field of music.

\section{DISCUSSION}

\section{A. Al-Kindi}

\section{Life History}

Al-Kindi his full name is Abu Yusuf Ya'qub ibn Ishaq ibn Al-Shabbah ibnu 'Imran ibn Muhammad Al-Ash'as ibn Qais Al-Kindi. Kindah, in which the name Al-Kindi is originated, is a prominent pre-Islamic tribe, which is a branch of the Bani Kahlan who settled in Yemen. Al-Kindi was born in Kufa around 185 AH / 801 AD into a rich and respectable family. His great grandfather, Al-Ash'as ibn Qais was a friend of the Prophet Muhammad SAW who died as syuhada' (people who died in the way of Allah) with Sa'ad ibn Abi Waqqas in the war between the Muslims and Persia in Iraq.

Meanwhile, his father, Ishaq ibn Al-Shabbah was the Governor of Kufa during the reign of Al-Mahdi (775-785 AD) and Al-Rasyid (786-809 AD). His father died when he was still a child, but he still had the opportunity to study well. Al-Kindi himself underwent five reigns of the Klahifah of the Abbas, which were Al-Amin (809-813 AD), Al-Ma'mun (813-833 AD), Al-Mu'tasim (833-842 AD), Al-Wasiq (842-847 AD) and AlMutawaqqil (847-861 AD). ${ }^{2}$

${ }^{1}$ Fauziah Ahmad, Al-Kindidan Al-Farabi (2010), p. 1.

${ }^{2}$ Sirajuddin Zar, Filsafat Islam: Filosof dan Filsafatnya (Edition I; Jakarta: PT. Raja Grafindo Persada, 2004), p. 37-38. 
We only get very little information about education. He moved from Kufa to Basrah, a center for Islamic language studies and theology. Then when he was young, he settled in Baghdad, the capital of the kingdom of Bani Abbas, which was also the center of intellectual life at that time. He was very diligent in studying various disciplines. Therefore, it is not surprising that he can master astronomy, geometry, natural sciences, astrology, exact sciences, music, meteorology, optics, medicine, mathematics, philosophy, and politics. His mastery of philosophy and other scientific disciplines has made him the first Muslim of Arab nationality in the ranks of leading philosophers. Because of that, he was considered worthy of the title of Failasuf al-'Arab (Arabic philosopher). ${ }^{3}$

The style of Al-Kindi's philosophy is not well known because his books on philosophy have been lost much more recently. Recently, approximately twenty AlKindi's treatises have been found in handwriting; those who are interested in studying Islamic philosophy, both the Orientalists and the Arabs themselves have published these treatises. Thus, it is easy for people to find clarity about Al-Kindi's position and understand his philosophy. According to Mustafa Abd al Rasiq, as in his book Mustafa Syahim entitled (Tarikh al fikr al falsafi al islam), said that Al-Kindi died in $252 \mathrm{H}$ (866 AD) ${ }^{4}$

Al-Kindi is a prolific Muslim philosopher in producing various kinds of scientific work. His writing is quite a lot in various disciplines. According to George Atiyeh said that his writings in various fields of science reached 270 treatises. The treatises were both by Ibn Nadim, and Qifthi categorized in 17 groups, namely: 1. Philosophy, 2. Logic, 3. Computation, 4. Globular, 5. Music, 6. Astronomy, 7. Geometry, 8. Spherical, 9. Medical, 10. Astrology, 11. Dialectics, 12. Psychology, 13. Politics, 14. Meteorology, 15. Dimensions, 16. First things, and 17 Specific species and chemistry.

Here are some of Al-Kindi's writings, i.e.:(Fi>'al-falsafat $a l-' U<l a, K i t a>b$ alHassi 'ala Ta'allum al-Falsafat, Risa>latila al-Ma'mu>n fi> al-illat wa Ma'lu>l, Risa>lat fi>Ta'lif al-A'da>d, Kita>b al-Falsafat al-Dakhilatwa-Al Masail al-Manthiqiyyat wal alMu'Tashahwa ma Fauqa al-Thabiyyat, Kammiyat Kutub Aristoteles dan Fi al- Nafs). ${ }^{5}$

${ }^{3}$ Sirajuddin Zar, Filsafat Islam: Filosof dan Filsafatnya, p. 38.

${ }^{4}$ Mustafa Syahin, Tarikh al-Fikr al-Falsafi fi al-Islam (Cairo: Daru al-Atsaqafah liNasyriwa-Tauzi'), p. 76.

${ }^{5}$ Sirajuddin Zar, Filsafat Islam: Filosof dan Filsafatnya. p. 42-43. 
Al-Kindi did not just translate Greek philosophical works, but he also concluded philosophical works of Hellenism. One of his great contributions is to harmonize philosophy and religion. After the era of the Caliph Al-Mu'tashim ended and the reign of the Caliph turned to al-Watsiq and al-Mutawakkil, the role of al-Kindi was increasingly narrowed. However, his captivated calligraphy had made the Caliph smitten. Caliph alMutawakkil then promoted him as palace calligraphers. However, that did not last long. ${ }^{6}$

As the initiator of pure philosophy in the Islamic world, Al-Kindi views philosophy as a noble science. Because, through philosophy, humans can learn about the first Divine cause and reality and are the cause of all other realities. For him, philosophy is the science of all sciences and the wisdom of all wisdom. Philosophy, in Al-Kindi's view, aims to strengthen religion and is part of Islamic culture.

\section{The Relationship between Philosophy and Religion}

Al-Kindi was the first Muslim to seek harmony between philosophy and religion or between reason and revelation. According to him, the two are not contradictory because each of them is the science of truth, while the truth is one. Philosophy includes Divinity, Allah'sOneness, and Allah's Superiority and other sciences that teach how to obtain what is useful and to stay away from what is harmful.Al-Kindi made a phenomenal contribution when he was able to bring philosophy and religion together. According to al-Kindi, the real function of philosophy is not to challenge the truth of revelation or to demand presumptuous superiority or demand equality with revelation. Philosophy must in no way put forward a claim as the highest way to truth and want to humble itself as a support for revelation. ${ }^{7}$

Al-Kindi introduced religion with philosophy on the grounds that philosophy is the science of truth, and religion is also the science of truth as well; therefore there is no difference between the two. The influence of the Sect of Mu'tazilah (a group who dissociated from Hasan al-Basri) was evident in the way he thought when he determined the ability of the human mind to know the secrets brought by the prophet

${ }^{6}$ Heri Sucipto, Cahaya Islam IImuan Muslim Dunia Sejak Ibnu Sina hingga BJ. Habibie (Edition I; Jakarta: Grafindo Khazanahllmu, 2006), p. 84.

${ }^{7}$ Heri Sucipto, Cahaya Islam IImuan Muslim Dunia Sejak Ibnu Sina hingga BJ. Habibie, p. 84-85. 
Muhammad SAW. According to Al-Kindi we should not be ashamed to admit the truth and take it from wherever it comes, even from other nations far from us. ${ }^{8}$

He defined philosophy as the knowledge of everything to the extent of human knowledge. Therefore, al-Kindi firmly said that philosophy has limitations and that it cannot overcome problems such as miracles, heaven, hell, and the afterlife. ${ }^{9}$ The following table is between philosophy and religion:

\begin{tabular}{|l|l|}
\hline \multicolumn{1}{|c|}{ Philosophy } & \multicolumn{1}{c|}{ Religion } \\
\hline True knowledge & True knowledge \\
\hline Truth results from rational arguments & $\begin{array}{l}\text { The truth of the results of the argument } \\
\text { is more valid and convincing because } \\
\text { of revelation }\end{array}$ \\
\hline Theology is part of Philosophy & Theology is the core of religion \\
\hline $\begin{array}{l}\text { The Purpose of Philosophy: Searching } \\
\text { for the Truth }\end{array}$ & $\begin{array}{l}\text { The Purpose of Philosophy: Practicing } \\
\text { the Truth }\end{array}$ \\
\hline $\begin{array}{l}\text { Humanities, thinking, learning, } \\
\text { pondering. }\end{array}$ & $\begin{array}{l}\text { Divinity, without the learning process } \\
\text { accepted by the Prophets }\end{array}$ \\
\hline
\end{tabular}

In conclusion, Al-Kindi is a pioneer in making efforts to integrate philosophy and religion or between reason and revelation. So it can be said that AI-Kindi has played a large and important role in Islamic philosophy.

\section{Divine Philosophy}

Al-Kindi's writings discuss divinity, among others (Fi Al Falsafa al Ula and Fi Wahdaniyyat Allah waTandhiJirm al-Alam). The writings can be seen that Al-Kindi's view of divinity is in accordance with Islamic teachings. According to him, God is a real form, not originating from nothing then becoming something that exists. It is impossible to not exist and always will be forever. God is a perfect existence and is not preceded by other forms. His existence does not end, while other forms are due to His existence. $\mathrm{He}$ is Almighty that cannot be divided, and there is no other substance that equals Him

\footnotetext{
${ }^{8}$ Ahmad Hanafi, Pengantar Filsafat Islam (Edition V; Jakarta: PT. Bulan Bintang, 1991), p. 60.

${ }^{9}$ Majid Fakhri, Sejarah Filsafat Islam, Sebuah Peta Kronologis (Edition II; Bandung: Mizan, 2002), p. 26-27.
} 
in all aspects. He did not give birth and was not born. Objects that exist in nature, according to Al-kindi have two essences, namely Ani'ah and Mahiah (i.e the nature that is universal in the form of certain species). ${ }^{10}$

From the description above, it can be comprehended that Al-Kindi examined the question of God, namely the nature of God, the existence of God, and the attributes of God. The Nature of God, according to Al-Kindi, God is existence, and His existence is a perfect existence, a form that haq (true) and not preceded by other forms. God's existence does not end while other beings are caused by His existence. And the nature of God is One in the sense that God is the only one.

To prove the existence of God, Al-Kindi propounded three arguments, namely:

1) There cannot be an object that exists by itself, so there must be a first and foremost creator.

2) The proposition of diversity and unity (human beings and their elements) that would not have been possible without someone to arrange it.

3) The proposition of Natural Baharu (Dependence/Limitations of motion and time on objects). ${ }^{11}$

The argument propounded by Al-Kindi above shows a very simple reason that can be accepted by all people, both those who are knowledgeable and for ordinary people.Besides that, it can also be concluded that according to Al-Kindi everything in the heavens and the earth's existence is in the hands of God.

\section{B. Al-Farabi}

\section{Life History}

The full name of Al-Farabi is Abu Nashr Muhammad ibn Muhammad ibn Tarkhan ibn Auzalagh al-Farabi. He was born in Wasij, a small village in the city of Farab, Transoxiana Province, Turkestan, which is now part of the Republic of Uzbekistan around $890 \mathrm{AD} .{ }^{12}$ In the Western world, al-Farabi is known by the name

${ }^{10}$ Harun Nasution, Falsafah dan Misticme dalam Islam (Jakarta: PT. Bulan Bintang, 1973), p. 16.

${ }^{11}$ Sirajuddin Zar, Filsafat Islam : Filosof dan Filsafatnya, p. 53.

${ }^{12}$ Thawil Akhyar Dasuki, Sebuah Kompilasi Filsafat Islam (Edirion I; Semarang: Toha Putra, 1993), p. 26. 
alpharabius or by the name of Avennaser ${ }^{13}$. His father was a general of Persian nationality and his mother was Turkish. Therefore, sometimes he is said to be of Persian descent and sometimes of Turkish descent. However, according to the teachings of Islam, which bases offspring on the part of the father, it is more still called Persian descent. ${ }^{14}$

His basic education is religious and language. He studied Islamic Jurisprudence (Fiqih), Hadith, and Qur'anic interpretation (Tafsir Alquran). He studied Arabic, Turkish, and Persian. When he was grown up, al-Farabi moved to Baghdad and lived there for about 20 years. He put his attention to the science of logic, and he learned it from Abu Bisyr bin Mattius. It seems that when he first arrived in Baghdad, he only had been mastered a handful of Arabic. He himself said that he learned it from Abu Bakr al-Saraj in exchange for the lessons of logic that al-Farabi gave him. ${ }^{15}$

After that, he moved to Harran (Iran), one of the Greek cultural centers in Asia, to study Greek logic with a Christian scholar, Yuhanna bin Hailan. ${ }^{16}$ Shortly after, alFarabi left Harran back to Baghdad.

In Baghdad, he spent his time teaching and writing. Al-Farabi authored a number of books on logic, Physical, Psychology, metaphysics, chemistry, political science, music, and others. But most of his work written in Arabic has been lost. Now it is estimated that there are only about 30 books left. ${ }^{17} \mathrm{It}$ is not known whether al-Farabi had experienced rapid development in his studies at Farab, but there is no doubt that in Baghdad he already had a mature insight.

${ }^{13}$ Miska Muhammad Amin, Epistemologi Islam (Edition III; Jakarta: UIP Press, 2006), p. 44.

${ }^{14}$ Sirajuddin Zar, Filsafat Islam : Filosof dan Filsafatnya, p. 65.

${ }^{15}$ Sudarsono, Filsafat Islam (Edition 1; Jakarta: Rineka Cipta, 1997), p. 30.

${ }^{16}$ Ahmad Hanafi, pengantar filsafat Islam, p. 81.

${ }^{17}$ Dewan Redaksi Ensiklopedi Islam, Ensiklopedi Islam (Edition V1; Jakarta: Ichtiar Baru Van Hoeve, 1997), p. 331 
Al-Farabi left Baghdad forever after General Tuzun from Dailam entered Baghdad and killed the Caliph Muttaqi in 940 AD. ${ }^{18}$ He lived briefly in Damascus until $330 \mathrm{H} / 942 \mathrm{M}$ and then he moved to Halab (Aleppo) because he received an invitation from the Hamdani Dynasty government who was in power at the time, namely Saifuddaulah. Al-Farabi lived a very simple life, whereas Amir Saifuddaulah was very kind to him and willing to guarantee the cost of his life with abundantwealth.

He taught in Aleppo, and thanks to his application, his students received scholarship assistance from the sultan. ${ }^{19} \mathrm{His}$ friendship with Amir Saifuddaulah was so good that he accompanied Amir on the journey to Damascus in 950 AD. It was in Damascus that al-Farabi later died at the age of 80 and was buried there. ${ }^{20} \mathrm{It}$ is said that he had also been to Egypt, which according to some information it was before he went to Aleppo. But according to other information, he went to Egypt about a year before he died. ${ }^{21}$

Al-Farabi understands five languages and studied philosophy, medicine, mathematics, chemistry, and music. He is a special lute player. ${ }^{22}$ According to lbn Khallikan's information, he mastered 70 languages. Perhaps the information was an overstatement. ${ }^{23}$ This just shows that his talent in the field of language is very prominent.

Al-Farabi shows himself as a Muslim who firmly holds religion, the successor of Plato in the field of logic and physics, and as a follower of Plotinus in the field of metaphysics. He is known as an exponent of Muslim Neoplatonism, which was started by Al-Kindi and continued by Ibn Sina. Al-Farabi may be said to be an encyclopedia of life. George Sarton, as quoted by Jamil Ahmad, said that Al-Farabi knew all the

${ }^{18}$ Tim Ensiklopedi, Ensiklopedi Tematik Dunia Islam Pemikiran dan Peradaban (t.tp.:Ichtiar Baru Van Hoeve, t.th.), p. 185.

${ }^{19}$ Cyril Glasse, The Concise Encyclopedia OF Islam terj. GhufranMas'adi, Ensiklopedi Islam Ringkas (Edition 11; Jakarta: PT Raja Grafindo Persada, 1999), p. 31.

${ }^{20}$ Tim Ensiklopedi, Ensiklopedi Temati Dunia Islam Pemikiran dan Peradaban, p. 185.

${ }^{21}$ Tim Ensiklopedi, Ensiklopedi Temati Dunia Islam Pemikiran dan Peradaban.

${ }^{22}$ Lois Larri, The cultural Atlas of Islam terj. Ilyas Hasan, Atlas Budaya Islam (Edition11; Bandung: Mizan, 2001), p. 340.

${ }^{23}$ Lan Richard Netton, Alfarabi and His School (Routledge: London, 1992), p. 4. 
scientific thought in his day. ${ }^{24}$ It has been said that Ibn Sina had studied the metaphysics book written by Aristotle four times, but had not yet understood its meaning. After he read Al-Farabi's Maqala fi Aqhradhi maba' da al-Tabi'ah (the essence of the metaphysical book), then he understood what had been difficult to understand. ${ }^{25}$

Based on the reality of his life journey, it is no exaggeration to say that he is the intellectual of his day. He has the nature of zuhud (afterlife) but is very productive in thinking. He is a figure that is enough to inspire several people afterward. His style of thinking has a slight resemblance to Fazlur Rahman who propoundedtatbiq (realizing in practice) as a systematic way to approach the Qur'an and Sunnah. Tatbiq provides a method for conducting ijtihad and drawing legal conclusions while providing clear direction on how to apply it. ${ }^{26}$

\section{Emanation Theory}

Emanation is a doctrine about the occurrence of nature. ${ }^{27}$ The theory was introduced by Plotinus (205-270 AD), a Greek philosopher who developed Plato's philosophy, whose teachings are called neo-platonism. While in Islam, the teaching of emanation was first introduced by al-Farabi, where al-Farabi believes that God is Almighty, unchanging, far from the material, far from many meanings, all-perfect and not gratuitous in anything. ${ }^{28}$

The process of emanation, according to al-Farabi is that God is "intellect" thinking about His oneself. Because God's thinking about Himself is a powerful force or energy, then that power creates something that is reason I. So, the Almighty created the one. In this one person or Intellect, I begin to have a lot of meaning. The object of

${ }^{24} \mathrm{Jamil}$ Ahmad, Hundred Great Muslim terj. Tim Penerjemah PustakaFirdaus, Seratus Muslim Terkemuka (Edition 1V; Jakarta: Pustaka Firdaus, 1996), p. 230.

${ }^{25}$ Sirajuddin Zar, Filsafat Islam: Filosof dan Filsafatnya, p. 67.

${ }^{26}$ Ma'adul Yaqien Makkarateng, "Metodologi Pemikiran Hukum Islam Fazlur Rahman. "AlBayyinah 3, no. 1 (2019): 108-120.

${ }^{27}$ LorensBagus, Kamus Filsafat (Edition II; Jakarta: GramediaPustakaUtama, 2002), p. 193.

${ }^{28}$ Ali Mudhafir, KamusTeoridan Aliran dalam Filsafat danTeknologi (Edition I; Jakarta: Gadjah Mada University Press, 1996), p. 75. 
Intellect l's thinking is God and himself. His thoughts about God produced Intellect II, and his thoughts about him produced the First Heaven. Reason II thinks comes to Intellect III and so on until Intellect $X^{29}$

Intellect $I$ to Intellect $X$ includes something immaterial, while intellect $X$ is the active mind, which is also called Jibril. ${ }^{30}$ It is related to the previous intellect and also relates to the intellect (mustafa>d) of humans who have practiced so that they are able to know and communicate with Intellect $X$ (Jibri). ${ }^{31}$

The elaborate process of al-Farabi's emanation can be described as follows: The first existence of God is called the First Intellect, which contains two aspects: first, in terms of its own nature which is the existence (mumkin) and the second, namely the real existence and which occurs because of the existence of God, as the Substance that makes.

1 From the thought of the First Intellect, in its position as a mandatory existence (real) because of God and as anexistence who knows himself, the Second Intellect will emerge. From the mind of the First Intellect, in its position as an existence (mumkin) and knowing itself, then arises the first sky or the farthest celestial existence.

2 From the Second Intellect, arises the Third Intellect and the second heaven or the fixed stars and their souls, in the same way as in the First Intellect.

3 Out of the Third Intellect came the Fourth Intellect and the planet Saturn (Zuhal) and its soul.

4 Out of the Fourth Intellect comes the Balsam and the Jupiter planet (alMusytara) and its souls.

5 Out of the Fifth Intellect came the Sixth Intellect and the planet Mars (Mariiah) and its souls.

6 Out of the Sixth Intellect came the Seventh Intellect and the Sun (asySyams) and its souls.

${ }^{29}$ The amount of intellects is limited to the number of 10 because according to Aristotle that there are 7 (seven) celestial bodies, then al-Farabi added al-falaq al-aqs\}a> (the farthest sky), al-kawa>kibal-s/a>bitah (fixed-stars) and Jibril. Al-Farabi believes so because according to Islamic teachings that the sky is the source of revelation and the final destination of mi'ra>j. See: Tim Ensiklopedi, p. 187.

\footnotetext{
${ }^{30}$ Yamani, Al-Farabi Filosof Politik Muslim (Bandung: Mizan, 2005), p. 28.

${ }^{31}$ Harun Nasution, Filsafat Agama (Jakarta: PT Bulang Bintang, 1973), p. 74.
} 
7 Out of the Seventh Sense came the Eighth Sense and the planet Venus (azZuharah) and its souls.

8 Out of the Eighth Intellect came the Ninth Intellect and the planet Mercurius ('Utaris) and their souls as well.

9 Out of the Ninth Intellect comes the Tenth Intellect and the moon (Qamar).

10 Tenth Reason, because this power of reason has been weakened, then it can no longer produce the same mind and only produce earth, spirits, and the first material, which is the basis of the four basic elements: water, air, fire, and earth. This Tenth Intellect is called (Intellect Fa'al) (active reason) or (wahib al-s\}uwar) (the giver of the form) and is sometimes called Jlbril, who deals with the life of the earth. ${ }^{32}$

\section{Human Philosophy}

(Al-Nafs) (soul) man as well as the origin of material emanating from the tenth Intellect. Unity between the soul and the body is an accidental unity, meaning that between the two, thereare different substances so that the destruction of the body does not bring the destruction of the soul. The human soul comes from the divine nature. ${ }^{33}$ While the body comes from (nature of $k h a l q$ ), shaped and moving. ${ }^{34}$

Lebihlanjut al-Farabimembagidayajiwakedalamtigatingkatan:

1) Power / (al-muharrika $>t$ ) power that can cause to live eat, maintain, develop.

2) The power of knowing / (al-mudrika>t) is the power of feeling and imagination so that they can feel, hear, and feel with the external senses.

3) Power of thinking / (al-nat\}iqa $>t)$ that is practical sense, theoretical sense. With this power, humans can think, set, and judge. ${ }^{35}$

${ }^{32}$ Rasyid Rizani, "TeoriEmanasi Al-Farabi” June25, 2013, http://konsultasi-hukumonline.com/2013/06/teori-emanasi-al-farabi/, July 28, 2015.

${ }^{33} \mathrm{Cf}:$ QS. Shad: 72.

${ }^{34}$ Ahmad Daudi, Allah dan Manusia dalam Konsepsi Syekh Nuruddin al-Raniry (Jakarta: Rajawali, 1983), p. 136.

${ }^{35}$ Harun Nasution, Islam ditinjau dari Berbagai Aspeknya (Edition II; Jakarta: UI Press, 1978), p. 49. 
From the power of thinking, theoretically divided into three levels, namely:

1) Potential Intellect / (al-hayyula $>n i>$ ), that is, a new intellect has the potential to think in the sense of releasing the meanings of its material.

2) Actual Intellect / (al-'aql wa al-fi'l) that is the mind that has been able to release the meanings of the material and those meanings have actually existed in the sense of reason, no longer in the form of potential but in actual form. ${ }^{36}$

3) Intellect (Mustafad /) is the intellect that has been able to capture the form solely, which is not associated with the material and has the ability to make communication with intellect $\mathrm{X} .^{37}$

\section{Prophecy}

Al-Farabi's argument about the existence of prophets is the fact that in mind and potentials of the human soul, towards differences in excellence in actuality. Therefore, it is not impossible that in mankind, there is someone whose heart is able to receive revelation, while others cannot. And with his superiority, he bears the task of conveying God's revelationto humankind.

Al-Farabi stated that the prophecy was obtained by the main man, called a prophet, not through their efforts. The Prophet is a human being who has the power of imagination (receives information to process it and then convey it to the power of thought) whose extraordinary ability, although still carrying out its usual functions, that extraordinary power still has a lot of power to connect with active intellect.Al-Farabi stated that it is not impossible for someone (the prophet) if the imagination reaches the peak of perfection of actuality. To receive when conscious (not sleeping) from active intellect, ideas about events that occur now or in the future and accept ideas about immaterial existences and other noble existences, and see them and be ideas received as prophecy (nubuat) (divinenews) about things that are divine.Al-Farabi also stated that the prophet has a soul with a sacred power so that his holy soul is subject to macro-natural power such as the submission of micro-natural power (one's body) to his

\footnotetext{
${ }^{36}$ Sirajuddin Zar, Filsafat Islam: Filosof dan Filsafatnya, p. 70.

${ }^{37}$ Harun Nasution, Filsafat Agama, p. 74.
} 
soul. With that holy power, the soul of the prophet can perform extraordinary events or miracles.

A distinctive feature of a Prophet for al-Farabi is to have a strong imagination in which the external sense objects cannot influence. When he deals with (intellect fa'al) he can receive visions and truths in the form of revelation. Revelation is an abundance from God through (intellectfa'al) (Jibri). The Prophet is able to relate directly to (intellectfa'al) without practice because Allah bestowed on him an intellect that has a holy power with a comprehension that is named (hads) while philosophers can relate to God through a trained (intellect mustafad) and strong comprehension so that they can capture things that are purely abstract from intellect $\mathrm{X} .^{38}$

By propounding material about prophets and philosophers who both communicate with the active intellect, it can be understood that Al-Farabi has shown that the sources of religious teachings brought by the prophets and philosophical sources produced by philosophers are the same (active intellect); therefore the truth of both must not be contradicting. By stating that, besides, the prophet has a soul with a holy power (though with the power of imagination), so there is no need to practice or strive to master scientific ideas. He also showed the privileges and strengths of prophets over philosophers.

\section{CONCLUSION}

Al-Kindi (185 H / 801 AD) was the first Muslim philosopher. According to AlKindi clearly stated that between philosophy and religion, there is no contradiction, The Harmony between philosophy and religion. Philosophy is defined as a discussion of what is right, and religion is also interpreted to explain what is right. Then the two discuss the right one. Furthermore, philosophy, in its discussion, uses reason and religion. And in the discussion about what is right also uses rational arguments.

Divine Philosophy, According to Al-Kindi, God is a perfect existence, an existence that is haq (true) and is not preceded by other beings. God's existence does not end, while others are caused by His existence. According to Al-Kindi, Allah is not the same as His creation, Allah is not counted, Allah is not divided, and $\mathrm{He}$ is Almighty.

${ }^{38}$ Harun Nasution, Akal dan Wahyu dalam Islam (Jakarta: Universitas Indonesia, 1983), p. 17. 
Al-Farabi (870-950 AD) is an intelligent Muslim philosopher who was crowned as the second teacher after Aristotle because of his mastery of logic. Al-Farabi, with his EmanationTheory, suggested that this nature happened because of the abundance of the one and the first existence. The first intellect was abundant so that the second intellect appeared, and so on until the tenth intellect.

Al-Farabi considered that every species of plant, animal, and human has a soul and can actualize into powers to realize actions through the organs of the body, and the human soul has potential. This potential can actualize into power to act but not with organs, and that is intellect. If potential intellect has actually existed in a person's soul, it means he already has the first perfection as a human being.

Al-Farabi's prophetic theory suggested that philosophical knowledge does not contradict the knowledge of the Prophet because both come from the same intellect fa'al as different from the way if the prophet communicates with intellect fa'al by using the power of imagination while philosophers usingintellectmustafad.

\section{REFERENCES}

Ahmad, Jamil. Hundred Great Muslim terj. Tim Penerjemah Pustaka Firdaus, Seratus Muslim Terkemuka. Ediiton 1V; Jakarta: Pustaka Firdaus,1996.

Amin, Miska Muhammad. Epistemologi Islam. Edition III; Jakarta: UIP Press, 2006.

Bagus, Lorens. Kamus Filsafat. Edition II; Jakarta: GramediaPustakaUtama, 2002.

Dasuki, ThawilAkhyar. Sebuah Kompilasi Filsafat Islam. Edition I; Semarang: Toha Putra, 1993.

Daudi, Ahmad. Allah dan Manusia dalam Konsepsi Syekh Nuruddin al-RaniryJakarta: Rajawali, 1983.

Dewan Redaksi Ensiklopedi Islam.Ensiklopedi Islam. Edition V1; Jakarta: Ichtiar Baru Van Hoeve, 1997.

Fakhri, Majid. Sejarah Filsafat Islam, Sebuah Peta Kronologis. Edition II; Bandung: Mizan, 2002. 
Glasse, Cyril. The Concise Encyclopedia OF Islam terj. Ghufran Mas'adi, Ensiklopedi Islam Ringkas. Edition II; Jakarta: PT Raja GrafindoPersada, 1999.

Hanafi, Ahmad. Pengantar Filsafat Islam.Edition V; Jakarta: PT. Bulanbinang, 1991.

Larri, Lois. The cultural Atlas of Islam terj. Ilyas Hasan, Atlas Budaya Islam. Edition 11; Bandung: Mizan, 2001.

Mudhafir, Ali. KamusTeoridanAlirandalamFilsafatdanTeknologi.Edition I; Jakarta: GadjahMada University Press, 1996

Nasution, Harun. Filsafat Agama. Jakarta: PT BulangBintang, 1973.

Akal dan Wahyu dalam Islam.Jakarta: Universitas Indonesia, 1983.

Falsafah dan Misticme dalam Islam.Jakarta: PT. BulanBintang, 1973.

Islam ditinjau dari Berbagai Aspeknya. Edition II; Jakarta: UI Press, 1978.

Netton, Lan Richard. Al-Farabi and His School. Routledge: London, 1992.

Sucipto, Heri. Cahaya Islam IImuan Muslim Dunia Sejak Ibnu Sina hingga BJ.Habibie. Edition I; Jakarta: Grafindo Khazanah IImu, 2006.

Sudarsono, Filsafat Islam. Edition 1; Jakarta: RinekaCipta, 1997.

Syahin, Mustafa. Tarikh al-Fikr al-Falsafi fi al-Islam. Cairo: Daru al-Atsaqafah liNasyriwa-Tauzi'

Tim Ensiklopedi, Ensiklopedi Temati Dunia Islam Pemikiran dan Peradaban. t.tp.:Ichtiar Baru Van Hoeve, t.th.

Yamani. Al-Farabi Filosof Politik Muslim.Bandung: Mizan, 2005.

Yaqien, Maadul. "Metodologi Pemikiran Hukum Islam Fazlur Rahman." Al-Bayyinah 3, no. 1 (2019): 108-120 
Zar, Sirajuddin. Filsafat Islam: Filosof dan Filsafatnya. Edition I; Jakarta: PT. Raja GrafindoPersada, 2004.

RasyidRizani, “TeoriEmanasi Al-Farabi”, 25Juni 2013, http://konsultasi-hukumonline.com/2013/06/teori-emanasi-al-farabi/, 28 Juli 2015. 